\author{
R. R. Imanov $^{1}$, A. A. Bayramov ${ }^{1,2}$ \\ ${ }^{1}$ War College of Armed Forces of the Azerbaijan Republic, Baku, Azerbaijan \\ ${ }^{2}$ Control Systems Institute of the Azerbaijan National Academy of Sciences, Baku, Azerbaijan
}

\title{
DEVELOPMENT OF FIELD SIGNAL CENTERS BASED ON THE MODERN TELECOMMUNICATION TECHNOLOGIES
}

\begin{abstract}
Nowadays, one of the main directions of the military management system development is the improvment and wide automation of field communication networks of the military authorities. Therefore, states continue to advance their tactical networks to counter these emerging threats, enable new forms of maneuver and maintain integration with military Information Technology services available stateside-all while taking advantage of rapid innovation from the commercial IT industry. Moreover, when analyzing electromagnetic compatibility of radio-electronic means, it is important to know the factors affecting on modules interaction in network. Radio-electronic means is the ability to work without any disturbance under the influence of coincident electromagnetic interferences, without interfering with the radio-electronic means used by the others radio-electronic sets. In this paper, the role of modern telecommunication technologies in development of field siqnal centers has been shown, and a military field signal center have been proposed to set up in the form of modules.
\end{abstract}

Keywords : signal center; network; management system; data transmission; module.

\section{Introduction}

Development of the military management system is one of the most important challenges facing each state in ensuring the defense capacity. Nowadays, one of the main directions of the military management system development is the improvment and wide automation of field communication networks of the military authorities. Therefore, states continue to advance their tactical networks to counter these emerging threats, enable new forms of maneuver and maintain integration with military IT services available stateside-all while taking advantage of rapid innovation from the commercial IT industry. Specific to network modernization, communicating securely with command-and-control and other units within the increasingly communications-reliant battlefront landscape is critical to ensure the success of the mission and the safety of warfighters. However, as the battlefield evolves and missions require units to be mobile and support myriad tactical capabilities (Wi-Fi, LTE [Long Term Evolution, a standard for high-speed wireless communication for mobile devices and data terminals], etc.), critical communications infrastructures are becoming more difficult to establish and maintain [1].

The progress of information technology requires from communications centers certain work on timely, accurate and confidential exchange of all types of information, further enhancing the effectiveness of its activities, as well as replacement of communication centers elements by means of modern requirements or re-processing electromagnetic compatibility and reconstruction of communication centers during modernization.

One of the most important problems in the deployment and operation of military-purpose field communication centers is the reconciliation of electromagnetic compatibility of modern radioelectronic means with existing old radio-electronic means. Radio-electronic means is the ability to work without any disturbance under the influence of coincident electromagnetic interferences, without interfering with the radio-electronic means used by the others radio-electronic means. As can be seen from this, the new radio electronic devices that have been commissioned should be positioned at the communication centers so that they do not create excessive barriers to their work with other highfrequency electromagnetic fields. Radio-electronic units of military-purpose communication centers are composed of three main elements: radio transmitters, radio receivers and antenna-feeder devices. Radio transmitters generate, modulate and enhance high frequency currents. The radio receiver's devices determine the electrical signals, strengthen the selection and strengthen it. Antenna-feeder devices, in turn, select electromagnetic dance in radio range assigned to it and transmit it to the spatial area by converting it into appropriate electrical currents. Each of these elements affects the electromagnetic compatibility separately.

When analyzing electromagnetic compatibility of radio-electronic means, it is important to know the factors affecting their interaction. First of all, there is a need for information on the characteristics of the radio transmitting device, such as radio obstacle or a source of useful signal. The radio frequency level of the radio receiver output depends significantly on the characteristics of the radio-transmitting device (such as the type and strength of the transmitter transmitted in the reception zone). The level of radio barriers on the radio receiver's output is substantially dependent on the directional properties of the antenna systems, the source of radio obstacle and the receptor, their compatibility in a specific area and the compression of the amplitude $[2,3]$.

Thus, every radio electronic facility operated at the military-generated field communication intersections has many parameters and indicators that affect its electromagnetic compatibility. It is also important to ensure that normal operation of several different radio electronic facilities in one station remains a serious and crucial issue. 
Additionally, innovations in the cloud, "internet of things," sensors, robotic and autonomous systems, analytics, artificial intelligence and deep learning are driving tactical network developers to consider deploying warfighting systems that are highly reliant on high-performance computing and storage. Yet, in the face of potentially degraded communications, those resources may only be available if deployed all the way out to the individual warfighter or small teams conducting operations in austere and hostile environments, such as forward operating bases or combat vehicles-locations known as the tactical network's edge [4].

In this paper, the role of modern telecommunication technologies in development of field siqnal centers has been shown, and a military field signal center have been proposed to set up in the form of modules.

\section{Modern telecommunication technologies and field siqnal centers}

Taking into account the achievements of modern digital technologies, the implementation of the process of integration of communication and automated management systems into a single information and telecommunication system is one of the important issues. This single system contains information, telecommunications and organizational measures.

When we talk about military information and telecommunication systems, they must be understood as the organizational and technical integrity of communications, automation forces and tools that provide information exchange with the use of information and network technologies. In this case, the information section can include database, information itself, mathematical software, technical means and linguistic maintenance.

The telecommunications part involves the the communication system and network technologies that determine the architecture, type, and operating rules of communication networks. Organizational measures can include legal, regulatory mechanisms that provide effective functioning of information and telecommunication systems [5].

One of the main direction of development of perspective information and telecommunication systems is the improvement of the field communication and management system, which is an integral part of the overall management system. There are some shortcomings of the currently operating field communication system which are make difficulties to integrate them into the single system and it is necessary to revise these issues. These are - a number of old modification of communication facilities in communications divisions and sections, the fact that some of the communication equipments are analogue and others are digital, modern technologies.

Additionally, it should be noted that, since the modern communications facilities used in the field communications networks themselves have different indicators and different tactical requirements, issues of electromagnetic compatibility remain unresolved.
The abovementioned problems in many cases, creates difficulties in fulfillment of electromagnetic compatibility issues for all radioelectronic means, vitality of communication networks, intelligence protection, convenient use of communication and automated manegment sistem tools, broadband maneuvers with communication channels, as well as communication security, timely and precise data transmission. The military communication system should ensure that the authorities have the opportunity to communicate by required channels and means at the scheduled time. Signal centers are the basis of the communications system, therefor it is required to undertake a number of measures to address the aforementioned issues [4].

It is also important to take into consideration the requirements of the modern forms and methods of predicting operations, the organization and implementation of combat operations, and the requirements of modern era in the management of troops and the weapons. In addition, operational and technical requirements to the prospective field signal centers, the capabilities of modern communication facilities, the organizational and technical structure of the signal centers and the technical supply of its elements should be specified. Besides, this system should also provide the transmission of various data and the provision of integrated communication channels for the full satisfaction of the information needs of the troops [6]. It should be noted that it is advisable to set perspective field signal senters in the form of unified digital communication facilities, complexes and newest telecommunication technologies, as well as accessible automated systems for everyone.

The apparatus - software tools, which is being implemented on the basis of technologies of integration of channels, communication, encryption and management, will allow to create new structurebased signal centers. These tools, in turn, will create conditions for the groundbreaking review of the structure of the signal centers, the rejection of their centralized construction and the creation of modern structured field signal centers, taking into account the development tendencies of the control stations [7].

As the main option for their further development and improvement it is possible to set up a military field signal center in the form of modules, In this case, the field signal center can be presented as a set of coordinated components. This, in turn, can make it easier for customers to use the types of communications they provide, as well as improve intelligence protection, survival and flexibility of signal centers. It is also reasonable to implement the principle of hybrid switching (switching of channels and packages) in perspective digital signal centers [5].

These field communication nets can include radio relay, cable (fiber-optic) communications, transmitters, switch equipment and radio communication facilities that allow authorities to access the network when they are in motion. An important objective in the design of field signal center is often to minimize equipment cost, 
complexity and power consumption whilst also minimizing the bandwidth occupied by the signal and/or transmission time. (Bandwidth is a measure of how rapidly the information bearing part of a signal can change and is therefore an important parameter for field signal centers design [8].

It is important to pay special attention to the automated management systems during the construction of the proposed field signal centers. Automated control systems in this case are designed to provide the management of planning, organization and quality control of communications channels, ensuring security of communications and data protection, ensuring a unified automated management system interconnection with communication systems of troops, and collection of information about the situation [9].

\section{The modern military field communication networks}

During the creation of modern military-purpose field communication networks, the following must be implemented:

- increasing network capabilities and overall communication capabilities by applying integrated switch devices and broadband digital channels;

- wide automation of communications management and communication processes with the use of high-efficiency computing techniques;

- integration of encryption, switching, signal transformation functions into one device by switching to the modular design of communication means;

- provision the establishment of communication equipment on a new element base;

- the application of fiber optical means, which allows to increase the level of agility and and the reliability of signal centers;

- increase the level of utilization of communication means, reduction of their service life;

- automation of repair and maintenance process to achieve more reliable communication;

- provision of direct access by separate means by the operator;

- application of communication means with higher interference and intelligence protection.

The installation of signal centers on a modular basis can provide not only communication interconnection, but also the integrity of the communication system's external interference, the higher level of vital in the conditions of the barriers, the agility, the unification of their organizationaltechnical structure. The development and improvement of the field signal centers implies the establishment of a single telecommunications network, which are based organization of digital networking technologies, modern digital channels, automation of switching process, distribution of channel resources and access to broadband access to the network, supporting and integrating all types of power supply with their own resources.

Modern information and telecommunication technologies, as well as hardware and software which were developed on their basis, allow for all types of information processing and communication issues to be carried out directly at the workplaces. A new class of modular, tactical data centers is becoming available for tactical and expeditionary programs, capable of hosting cloud and storage, artificial intelligence and analytics applications. Using ultra-small form-factor modules for computer, storage and networking functions that reduce size, weight and power requirements, these systems can be deployed dismounted, at forward operating bases, in command posts, and on ground vehicles and aircraft-supporting a diverse array of use cases in disconnected, intermittent and limited environments. The widespread expansion of the nomenclature of telecommunication services to users requires from field signal centers multicast communication networks [1].

In front of mentioned multilevel communication networks stnading a difficult task to reconcile the transmission of different information across a single network infrastructure. At that time, its features are also subject to serious requirements.

First, the minimum network capability for each type of traffic should be ensured. Because, the multithreaded networks need to be set up for each traffic type, the transmission speed agreed upon with each intermediate network device. Transmission of a traffic type should not negatively affect others. Each attachment (video, data base, etc.) running on the network must be separately provided with a specific agreed network of that network.

Second, minimal possible downtime for multimedia traffic should be provided. The use of long information packets for data transmission is more efficient. Thus, the execution of these operations may reduce the useless use of the network. However, transmission of voice or video traffic may become a problem.

Documents sharing networks can be created at the expense of the properties (topologies) of the respective local computing networks, which have access to the field communication networks for the exchange of information with the top headquarters, interacting and controlling entities of the subordinate units. This organization can provide an informationalcomputing system with distributed functions, which optimally assists in the solution of exchange tasks with all types of information. The application of multicontour local computing networks in signal centers and in their elements can be used to reduce the number of communications devices, as well as to raise the operational-tactical and technical characteristics of the field communications networks.

\section{Conclusion}

Thus, in this paper, the role of modern telecommunication technologies in development of field siqnal centers has been shown, and a military field signal center have been proposed to set up in the form of modules. Modern perspective telecommunication technologies and their integration capabilities create high-speed digital networks in a vast space. These 
networks can, in turn, provide transmission of all types of information and a range of additional communication services which are specific to the military. The field signal centers always must be ready to launch at the right time and be ready to expand the communication system. Therefore, it is necessary to take into consideration the conditions provided for the solution of the issues of the application of new technologies and techniques in the development and improvement of the field siqnal centers.

\title{
REFERENCES
}

1. Zlobin, V.I., Ivashenko, M.V. and Ivanova, Q.V. (2005), Intellectual adaptive communication and management systems, Monoqraph, RF MOD, Moscow, 276 p.

2. Bichovski, M.A. (2006), The control of radio spectrum and electromagnetic compatibility of radio systems, EKOTREDZ, Moscow, $376 \mathrm{p}$.

3. Маккоv, N.A. and Pudovkin, A.P. (2007), Electromagnetic compatibility of radioelectronic means, TGTU, 49 p.

4. Samochin, V.F. (2008), "Improvment and development mobile communication networks", Military idea, No. 9, pp. 5-11.

5. Imanov, R. and Bayramov, A. (2019), "Analysis of the communication part of command centers", National Security and Military Sciences, No. 5 (1), Baku, pp. 14-21.

6. Karmashova, V.S. and Kechieva, L.N. (2004), EMC for products developers, Technology, Moscow, 290 p.

7. Vasilev, V.I. (1987), Communication system, High school, Moscow, 280 p.

8. Qalkin V.A. (2007), Digital mobile radio communication, Manual for university, Helpline-Telecom, Moscow, $432 \mathrm{p}$.

9. Garstka, John J. (2003), "Network Centric Operations Conceptual Framework Version 1.0", IT Value in the Net centric Organization: Integrating Commercial and Military Perspectives, December 9-10, 2003, available at: https://apps.dtic.mil/dtic/tr/fulltext/u2/a457620.pdf.

\section{ВідОМОсті ПРО АвтOPIB / ABOUT THE AUTHORS}

Іманов Р. Р. - ад’юнкт, Військова Академія Збройних Сил Азербайджанської Республіки, Баку, Азербайджан; R. R. Imanov - adjunct, War College of Armed Forces of the Azerbaijan Republic, Baku, Azerbaijan; e-mail: imanov-said@mail.ru; ORCID ID: http://orcid.org/0000-0003-2408-9786.

Байрамов Азад Агалар оглы - доктор фізико-математичних наук, професор, професор-консультант, Військова Академія Збройних Сил Азербайджанської Республіки, Баку, Азербайджан;

Azad Agalar oğlu Bayramov - Doctor of Physics and Mathematics, Professor, National War College of Armed Forces of the Azerbaijan Republic; Control Systems Institute of the Azerbaijan National Academy of Sciences Baku, Azerbaijan; e-mail: azad.bayramov@yahoo.com; ORCID ID: https://orcid.org/0000-0001-6672-2338.

\section{Розвиток польових вузлів зв'язку на основі сучасних телекомунікаційних технологій}

\author{
Р. Р. Іманов, А. А. Байрамов
}

Анотація. В даний час одним з головних напрямків розвитку військової системи управління $\epsilon$ поліпшення $\mathrm{i}$ повсюдна автоматизація управління військових польових мереж зв'язку. Тому продовження розвитку їх тактичних мереж запобігає виникненню загроз, створює нові форми маневру i інтеграцію 3 військовими сервісними інформаційними технологіями, які пов'язані з швидко розвиваються інноваціями в комерційній IT індустрії. Більш того, при аналізі електромагнітної сумісності радіоелектронних засобів зв'язку важливо враховувати фактори, що впливають на взаємодію модулів в мережі. Радіоелектронні пристрої можуть працювати без будь-якого порушення під впливом електромагнітної інтерференції, не впливаючи на інші засоби в радіоелектронної установці. У даній статті відзначена роль сучасних телекомунікаційних технологій у розвитку польових вузлів зв'язку, запропонований метод модульного побудови військових польових вузлів зв'язку.

Ключ ов і слов а : вузол зв'язку; мережу система управління; передача даних; модуль.

Развитие полевых узлов связи на основе современных телекоммуникационных технологий

\section{Р. Р. Иманов, А. А. Байрамов}

Аннота ция. В настоящее время одним из главных направлений развития военной системы управления является улучшение и повсеместная автоматизация управления военных полевых сетей связи. Поэтому продолжение развития их тактических сетей предотвращает возникновение угроз, создает новые формы маневра и интеграцию с военными сервисными информационными технологиями, которые связаны с быстро развивающимися инновациями в коммерческой ИТ-индустрии. Более того, при анализе электромагнитной совместимости радиоэлектронных средств связи важно учитывать факторы, воздействующие на взаимодействие модулей в сети. Радиоэлектронные устройства могут работать без всякого нарушения под влиянием электромагнитной интерференции, не оказывая воздействия на другие средства в радиоэлектронной установке. В данной статье отмечена роль современных телекоммуникационных технологий в развитии полевых узлов связи, предложен метод модульного построения военных полевых узлов связи.

Ключевы е слов а : узел связи; сеть система управления; передача данных; модуль. 